\title{
A QUALITY ASSURANCE FRAMEWORK FOR SULPHONIC ACID-COATED SAND USED IN 3D PRINTING APPLICATIONS
}

\author{
P.J.M. van Tonder ${ }^{1 *}$, D.J. de Beer ${ }^{2} \&$ J.H. Wichers ${ }^{3}$
}

\section{ARTICLE INFO}

\section{Article details}

Presented at the $21^{\text {st }}$ annual

international conference of the Rapid Product Development Association of

South Africa (RAPDASA), held from 4-6 November 2020.

Available online $\quad 11$ Nov 2020

\section{Contact details}

Corresponding author

malanvt@vut.ac.za

\section{Author affiliations}

1 Technology Transfer and Innovation Department, Vaal University of Technology, South Africa

2 Chair in Innovation and Commercialisation of Additive Manufacturing, Central University of Technology, South Africa

3 Department of Mechanical Engineering, North West University, South Africa

ORCID ${ }^{\circledR}$ identifiers

P.J.M. van Tonder

https://orcid.org/0000-0003-4756-8747

D.J. de Beer

https://orcid.org/0000-0003-0175-9556

J.H. Wichers

https://orcid.org/0000-0003-1237-7182

\section{DO}

http://dx.doi.org/10.7166/31-3-2447

\section{ABSTRACT}

The need for companies to adopt a quality management strategy has significantly increased in recent times as a result of global competition and more demanding customers. It is important to integrate quality throughout the product lifecycle, which includes the design phase. The purpose of the paper is to develop a quality assurance framework for the local production of chemical-coated sand used in the Voxeljet VX1000 printing process. The framework could be used as a basic structure to develop the necessary processes, procedures, and work instructions to ensure the quality of local chemical-coated sand.

\section{OPSOMMING}

Die behoefte van maatskappye om 'n gehaltebestuur strategie aan te neem het onlangs noemenswaardig toegeneem as gevolg van globale mededinging en meer veeleisende kliënte. Dit is belangrik om gehalte deurgaans met die produk lewensiklus te integreer, insluitend tydens die ontwerpfase. Die doel van hierdie artikel is die ontwikkeling van 'n gehalteversekeringsraamwerk vir die plaaslike produksie van chemiesbedekte sand wat in die Voxeljet VX1000 drukproses gebruik word. Die raamwerk kan gebruik word as die basiese struktuur om die noodsaaklike prosesse, prosedures en instruksies te ontwikkel om die gehalte van die plaaslik vervaardigde sand te verseker.

\section{PRINTING OF MOULDS AND CORES FOR THE SAND-CASTING PROCESS}

The sand-casting process is considered to be one of the most popular casting methods owing to its economic characteristics. The conventional sand-casting process requires a pattern to create the geometry of the end product in a refractory material. The refractory material is then bonded, using a clay, organic, or inorganic binder system. Silica sand is the most common refractory used in foundries, but alternative refractory materials include Olivine sand, Zircon sand, and Chromite sand. Once the bonding or curing process is complete, the mould is assembled, and metal is poured into the cavity to create the final metal part. After the metal has solidified, the sand mould is broken apart to retrieve the casted part. Although the conventional sand-casting process is well-known and well-developed, it remains a challenge to fabricate metal castings with complex geometries. The geometric freedom offered by AM technology is thus an important asset that can be used in combination with conventional processes [1]. 
The Vaal University of Technology (VUT) positioned itself to provide cutting-edge services to the foundry industry, with the aim of making local foundries more competitive on a global scale. The services include casting simulation, printing sand mounds and cores, and printing polymethyl methacrylate (PMMA) investment casting patterns. In 2011 the VUT procured a Voxeljet VX1000 platform, which uses a binder jetting printing process to print sand moulds and cores directly. The printing process uses a furan no-bake binder system to create a chemical bond between the sand particles, and is well-known in the traditional foundry industry. Although the Voxeljet uses a similar binder system to that of conventional furan foundries, the printing process selectively deposits the furan binder on precoated sulphonic acid sand layers rather than ramming or blowing a sand/furan/acid activator mixture into a core box or mould pattern [2]. The Voxeljet printing process is illustrated in Figure 1.

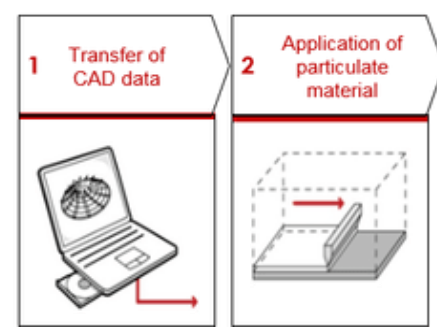

\section{PURPOSE OF THE STUDY}

Although the printing process would assist local foundries in becoming more competitive, it is still regarded as expensive. The high printing cost could be directly linked to expensive original equipment manufacturer (OEM) raw materials and freight costs. The VUT identified the need to localise the printing material to reduce the direct costs associated with the printing process. However, this poses a risk to the quality of the printed components, as no quality assurance measures are available for chemical-coated sand. For this reason a quality assurance framework needed to be developed.

\section{METHODOLOGY}

The need for companies to adopt a quality management strategy has significantly increased in recent times as a result of global competition and more demanding customers. There are various definitions of 'quality' but, in essence, it can be described as the collection of data about a customer's demands, since they are crucial arbiters of quality assessment. Providing quality products will help to maintain customer satisfaction and loyalty while reducing the cost of goods by avoiding replacing or repairing faulty goods. It is essential to integrate quality into the entire product lifecycle, which includes the design phase [4]. One of the most popular quality management strategies is ISO9001, an internationally recognised quality standard that specifies requirements for a quality management system. Quality assurance (QA) is an integral part of ISO9001, which builds confidence that services or products will meet the predefined quality requirements. QA can be broken down into processes, procedures, and work instructions, and ensures that planned activities are done correctly. Although ISO 9001:2015 has relaxed the strict requirement for quality management documentation, to satisfy the remaining documentation requirements, and (often more important) to implement the quality management system (QMS) properly, processes, procedures, and work instructions are typically still employed [5]. The QA framework developed in this research study could be used as a basic structure or guideline for the development of chemical coating processes, procedures, or work instructions to ensure that the coated sand meets the customer's requirements.

Quality by design $(\mathrm{QbD})$ was identified as a suitable methodology to aid the development of a QA framework for the chemical-coated sand process. The method is widely used by both the automotive and the pharmaceutical industries, and is known to reduce the risks associated with the development cycle while simultaneously fostering rational design thinking to avoid trial-and-error situations. QbD promotes a concurrent, simultaneous, or parallel engineering approach, since all the major development functions are required to be performed at the same time. The $\mathrm{QbD}$ methodology consists of eight sequential steps to create a better understanding of a product/service and its manufacturing process, which includes the identification and control of all the variables to ensure quality [6]. 


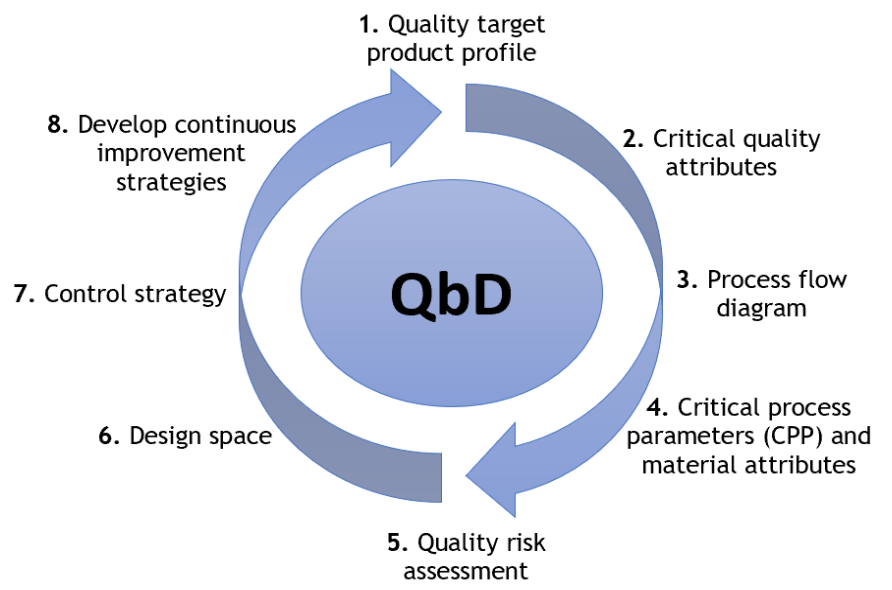

Figure 2: QbD method

Each of the steps in Figure 2 was applied to the sand chemical coating process, and will be summarised to serve as a QA framework for the chemical-coated sand process. The different QbD steps are described below.

\subsection{Quality target product profile}

The quality target product profile (QTPP) describes the quality characteristics of the product, and sets a clear goal for the development process. Usually the profile is developed using expertise from multiple professionals who know and understand the industry, clients' needs, and the product. 'Quality' can be preserved in several ways and can be broken down into five high-level quality approaches: the transcendental perspective, and the user-based, manufacturing-based, value-based, and product-based views. These high-level quality approaches can then be further broken down into several quality dimensions that were developed by David Gravin [7]. These dimensions are indicators based on the target market and customer needs. The quality dimensions are performance, features, reliability, conformance, durability, serviceability, aesthetics, and perceived quality. Using this approach, it is possible to capture how the client defines quality, and how they are used as the point of focus throughout the QbD methodology [8]. The QTPP was developed using the researcher's experience with the Voxeljet printing technology and the casting industry, and is shown in Table 1. Please note that the manufacturing and value-based quality QTPP falls outside the scope of this research study, and will not be discussed.

Table 1: QTPP of chemical-coated sand

\begin{tabular}{|c|c|c|}
\hline $\begin{array}{l}\text { Quality } \\
\text { approaches (high- } \\
\text { level) }\end{array}$ & $\begin{array}{l}\text { Quality } \\
\text { indicators }\end{array}$ & Description \\
\hline $\begin{array}{l}\text { Manufacturing- } \\
\text { based }\end{array}$ & Features & $\begin{array}{l}\text { Chemical-coated sand that offers a traceable manufacturing process and is } \\
\text { necessary for a QMS system. }\end{array}$ \\
\hline Value-based & Performance & $\begin{array}{l}\text { The performance of the local coated sand should be comparable to the OEM } \\
\text { coated sand, but at a lower cost. }\end{array}$ \\
\hline Product-based & Reliability & $\begin{array}{l}\text { The chemical-coated sand should consistently perform within specification. } \\
\text { There are no existing specifications for chemical-coated sand used in } \\
\text { additive manufacturing technologies. Thus the OEM sand will serve as a } \\
\text { reference. If the sand performs out of specification, it will affect the 3D } \\
\text { printing process. }\end{array}$ \\
\hline User-based & Conformance & $\begin{array}{l}\text { Adheres to the requirements of the target group. The target group, in this } \\
\text { case, would be sand foundries. }\end{array}$ \\
\hline
\end{tabular}

\subsection{Critical quality attributes}

The critical quality attributes (CQAs) are the product characteristics that need to be contained within certain limits to ensure that they conform to the desired quality level, defined in the QTPP. The CQAs of the chemical-coated sand were identified by performing an in-depth literature study structured around two main elements: the refractory material, and the process of coating the refractory material [8]. 


\subsubsection{Refractory material}

The refractory material used in the sand-casting process can affect the quality of the final castings, and should be carefully selected and controlled. Schleg [9] compiled a list of important aspects to keep in mind when choosing refractory material for the sand-casting process. The list, shown in Table 2, can be divided into two main groups: refractory requirements, and supply chain management aspects [9]. Only the refractory requirements were considered for this research study.

\section{Casting material and metal/sand ratio}

The casting material's composition and the physical size of the casting are listed as key aspects to consider when selecting a refractory material. The composition of the cast material will determine the melt and pouring temperature, which may react with the chemicals used during the moulding process. The metal/sand ratio is used to indicate the mechanical and thermal strain during the casting process. A high ratio will indicate that the refractory material is exposed to high strain during the casting process, which could result in mould failures [9]. The casting material and metal/sand ratio were not considered as CQAs, as they are dependent on the mould design process, which falls outside the scope of this research study.

\section{AFS GFN, particle size distribution, and grain shape}

The American Foundry Society (AFS) grain fineness number (GFN), the particle size, and the grain shape are dependent on the physical properties of the sand sample. Higher AFS values indicate that the refractory material consists of finer sand, which generally provides a smoother mould and casting surface finish. The AFS GFN specification depends on the casting application, but usually ranges from 25 to 170 [9]. The particle size distribution, also referred to as the 'screen distribution', illustrates the distribution profile of a given sand sample. In traditional mould-making methods, the particle distribution influences the mould packing density, which in turn influences the mould strength and permeability [10]. The physical shape of the sand grains (grain shape) also plays an important role in conventional mould and core making. The shape influences the packing density, flowability, and binder requirement of the sand used for mould and core production. Foundries usually prefer a subangular grain distribution because of the acceptable binder requirement, flowability, permeability, and mould strength. The effect of the grain shape on the binder requirement can be explained by the change in the grain surface area of round vs angular grain shapes [9].

Table 2: Refractory material selection list [9]

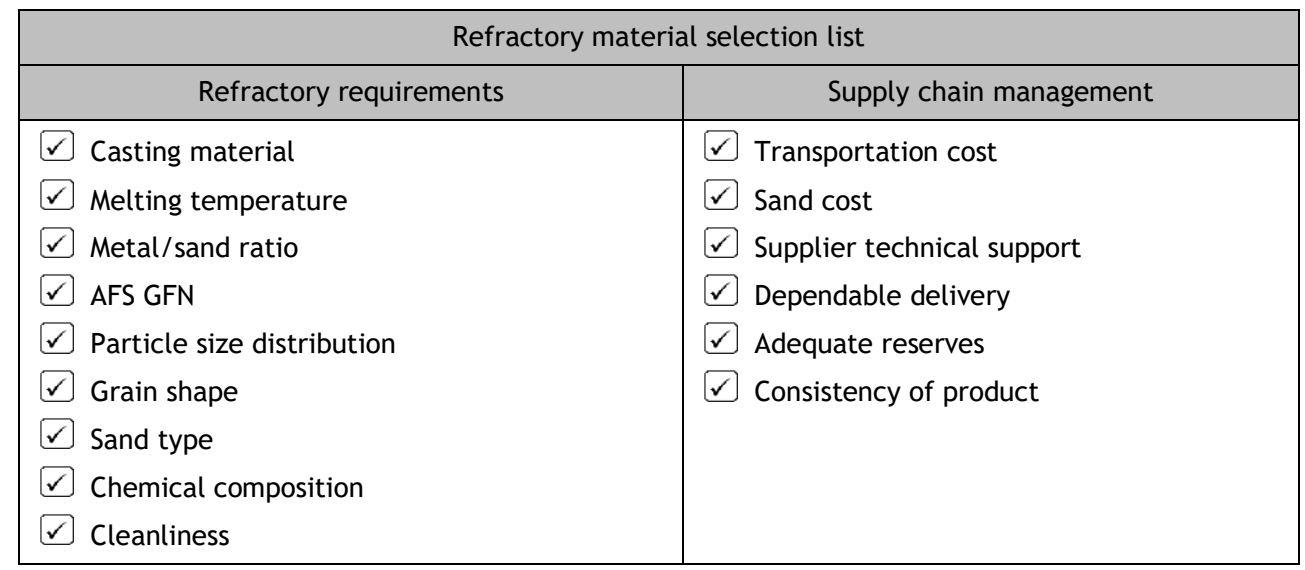

\section{Chemical composition}

Chemical composition, listed in the sand selection list, refers to the chemical composition of the sand and not the chemical binder system used in the moulding process. The chemical composition of a sand sample affects the fusion point, the $\mathrm{pH}$, and the acid demand value (ADV). The fusion point indicates the sand's refractoriness, which specifies the melting temperature of the sand. If the metal pouring temperature exceeds the fusion point, it can result in burn-on casting defects. The $\mathrm{pH}$ and ADV are used to indicate the acidity or basicity of the sand, and are used to select an appropriate resin binder system for the moulding process. Impurities in the sand will change both the $\mathrm{pH}$ and the ADV, depending on whether they are watersoluble or soluble in dilute acid [9]. The ADV is used to determine whether a specific sand is compatible with an acid catalysed binder system, as shown in Table 3. 
Table 3: Acid demand value

\begin{tabular}{|l|l|l|}
\hline ADV $\leq 6 \mathrm{ml}$ & $6 \mathrm{ml}>\mathrm{ADV} \leq 10 \mathrm{ml}$ & ADV $>10 \mathrm{ml}$ \\
\hline $\begin{array}{l}\text { The sand requires a low } \\
\text { amount of acid, which makes } \\
\begin{array}{l}\text { it suitable for acid catalysed } \\
\text { binder systems }\end{array}\end{array}$ & $\begin{array}{l}\text { The sand requires a high } \\
\text { amount of acid, but is still } \\
\text { considered suitable for acid } \\
\text { catalysed binder systems }\end{array}$ & $\begin{array}{l}\text { Not suitable for catalysed } \\
\text { binder systems }\end{array}$ \\
\hline
\end{tabular}

\section{Cleanliness}

Natural silica sand usually contains numerous impurities, depending on where the sand was mined. These impurities can include clay, heavy iron metals, salts, and calcium carbonite, all of which affect the chemical composition of the sand. Thus, sand supplied to foundries undergoes a washing process to reduce and control the impurities present in the sand. The washed sand is also dried to get rid of the excess water that may still be attached to the sand grains. According to the literature, a high sand moisture level can result in casting defects owing to the formation of large volumes of steam during casting and reduced mould strength in resin-bonded systems [11].

\subsubsection{Chemical coating process}

As highlighted previously, the Voxeljet VX1000 printing process requires the sand to be precoated with a sulphonic acid. The CQAs that were identified for the chemical coating process included:

\section{Chemical bonding}

The furan cold-setting process is well-known in the traditional casting industry, and provides good flexibility, strength, rapid curing time, and high reclamation yields. The furan binder curing process starts when mixed with an acid activator. During the curing process, the furan binder will undergo a polycondensation process owing to the cross-linking of the chemical chains, and will result in the sand particles sticking together [12]. The curing rate is directly proportional to the moisture, the ambient temperature, and the type of acid catalyst used. The mixing ratio between the furan and the acid is usually specified by the chemical supplier, as an increased acid/furan ratio will tend to increase the curing rate, but will result in a furan becoming brittle and decreasing the cohesiveness of the mould or core. The inverse is also true: a reduced acid/furan ratio will result in a prolonged curing rate and a weak mould or core. Generally, the resin content will vary between 0.8 and 1.2 per cent, based on the sand weight (BOS), and the catalyst will vary between 20 and 50 per cent, based on the binder weight [13]. The desired operating temperature for the curing process ranges from $24^{\circ} \mathrm{C}$ to $30^{\circ} \mathrm{C}$.

\section{Flowability}

The Voxeljet VX1000 printing process uses a recoater to add individual layers to each other. After depositing a layer, the desired layer geometry will be printed with the furan binder. The recoating process will continue until the desired height of the build is achieved. The recoater consists of a sand storage hopper with a narrow opening at the bottom. The opening needs to be adjusted to ensure that the sand does not flow freely through it. Under normal conditions the sand will remain static owing to inter-particle forces, such as the frictional and capillary forces between the sand particles [9]. A representation of the recoater is shown in the figure below.

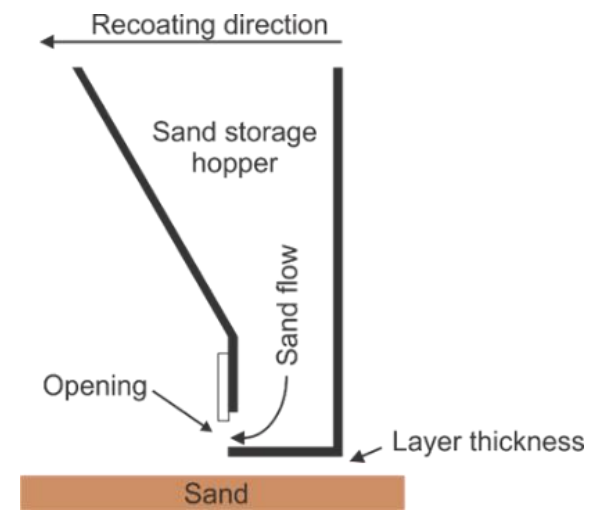

Figure 3: Recoater

When a vibrational force is introduced, the sand will start to flow through the opening owing to reduced frictional forces between the particles. The sand will only flow when the gravitational force exceeds the sum of the frictional and capillary forces [14]. The frictional forces are dependent on the composition, 
density, shape, and size of the individual sand particles. The capillary forces between the particles are a result of capillary bridges that form in the gaps between individual particles. These bridges only form in low saturation situations, and the capillary force will depend on the particle diameter, the distance between the connected particles, the wetting angle, and the bridge volume ([15]. Low sand flowability can result in recoating errors that may cause decreased layer adhesion, lost mould features, and lower mould density. The flowability of granular material can be determined using the 'angle of repose' measurement method, which measures the steepest angle of descent relative to the horizontal plane. These angles can vary from $0^{\circ}$ to $90^{\circ}$; lower angles represent a better flowability. The relationship between the angle of repose and flowability is demonstrated in Table 4 [16].

\section{Table 4: Angle of repose vs flowability [16]}

\begin{tabular}{|l|l|}
\hline Angle of repose $\left(^{\circ}\right)$ & Description \\
\hline$\leq 30$ & Excellent flowability \\
\hline $31-35$ & Good flowability \\
\hline $36-40$ & Reasonable flowability \\
\hline $41-45$ & Passable flowability \\
\hline $46-55$ & Poor flowability \\
\hline $56-65$ & Very poor flowability \\
\hline$>66$ & Extremely poor flowability \\
\hline
\end{tabular}

According to ASK, the chemical supplier of the catalyst product, freshly coated sand should be allowed to rest for a minimum of two days to improve its flowability. The resting period allows the water that was used as the acid carrier to evaporate, and reduces the capillary forces and improves sand flowability [17].

\subsection{Process flow diagram}

The process flow diagram (PFD) is developed by determining the activities, procedures, or processes that are necessary to manage or control the CQAs identified in Section 4.2. These activities, procedures, or processes are then visually mapped to improve the understanding of the relationships between the critical procedures, which is necessary to control the quality of the coated sand [6]. The procedures and activities that were identified are shown in Table 5.

Table 5: Procedures and activities

\begin{tabular}{|l|l|}
\hline Critical quality attributes & Procedure or activity name \\
\cline { 1 - 1 } AFS GFN & \multirow{2}{*}{ Physical classification } \\
\cline { 1 - 1 } Particle distribution & \\
\hline Grain shape & \\
\hline AFS clay content & Cleanliness \\
\hline Water content & Chemical composition \\
\hline ADV & \\
\hline Sintering temperature & Resting period \\
\hline Resting & Catalyst verification \\
\hline \% acid/sand weight & \\
\hline Flowability index & Flowability verification \\
\hline
\end{tabular}

The chemical coating process consists of several sequential procedures and activities, and is shown in Figure 4. The 'coating' and 'packing and shipping' procedures fall outside the scope of this research study, and will not be addressed. 

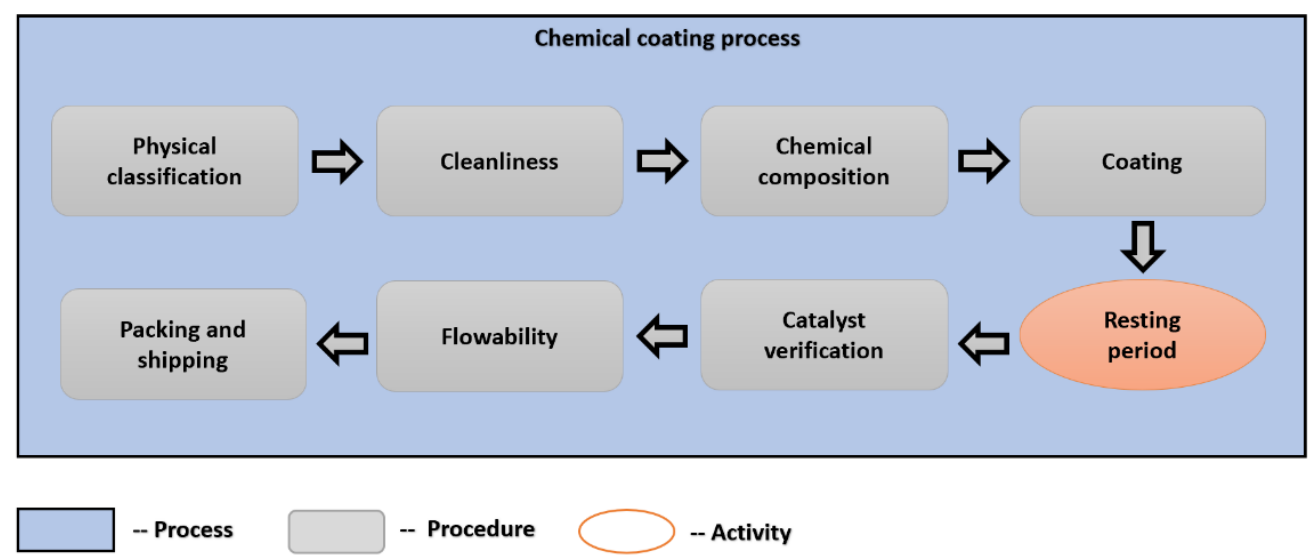

Figure 4: Process flow diagram

\subsection{Critical process parameters and critical material attributes}

In the critical process parameters (CPP) and critical material attributes (CMA) are sets of parameters used to monitor and control the CQAs that were identified for the procedures and activities listed in Table 5. The CPP and CMA are used to ensure the consistency, repeatability, and accuracy of the sand-coating process [6]. The CPP and CMA were determined from the literature in both the foundry and the additive manufacturing fields.

\subsubsection{Physical classification procedure}

The key critical attributes of the physical classification process include the AFS GFN, sand distribution, grain shape, and AFS clay content. These attributes are affected by the sand's origin, mining method, and screening processes. The CMAs that were identified for the physical classification procedure are shown below.

Table 6: Physical classification procedure of CMA

\begin{tabular}{|l|l|l|}
\hline $\begin{array}{l}\text { Critical } \\
\text { attributes }\end{array}$ & Recommended range & CMA \\
\hline AFS GFN & $\begin{array}{l}\text { According to Brown, an AFS GFN range of between } 50 \text { and } 60 \text { is } \\
\text { the most commonly used and accepted for silica sand. This } \\
\text { range offers a good surface finish and requires low binder } \\
\text { levels [18]. However, it should be noted that foundries can } \\
\text { specify the AFS GFN range to achieve a specific surface finish. }\end{array}$ & $\begin{array}{l}\text { If not specified by the client as a } \\
\text { requirement, an AFS in the range } \\
\text { of 50 to } 60 \text { offers a good surface } \\
\text { finish and requires low binder } \\
\text { levels. }\end{array}$ \\
\hline $\begin{array}{l}\text { Sand } \\
\text { distribution }\end{array}$ & $\begin{array}{l}\text { According to Brown, sand with a 95\% spread over 4 to 5 screens } \\
\text { offers a good packing and minimises expansion defects [18]. } \\
\text { Schleg mentioned that foundries usually prefer a three- or } \\
\text { four-screen sand, owing to the mould compaction advantages } \\
\text { [9]. }\end{array}$ & $3-5$ screen sand \\
\hline Grain shape & $\begin{array}{l}\text { Rounded and sub-rounded offer good flowability and } \\
\text { permeability with high strength at low binder additions [18][9]. }\end{array}$ & Rounded to sub-rounded \\
\hline $\begin{array}{l}\text { AFS clay } \\
\text { content }\end{array}$ & $\begin{array}{l}\text { No-bake processes require the lowest possible clay content. } \\
\text { However, a maximum allowable clay content of 0.3\% is } \\
\text { specified. An increase in the clay content will influence the } \\
\text { sand refractoriness and chemical binder requirement [11]. }\end{array}$ & 0.3\% \\
\hline
\end{tabular}

\subsubsection{Cleanliness procedure}

The cleanliness procedure is necessary to ensure that the sand adheres to the correct moisture level. The CMA that was identified for the process is shown in Table 7.

Table 7: Cleanliness procedure CMA

\begin{tabular}{|l|l|l|}
\hline $\begin{array}{l}\text { Critical } \\
\text { attributes }\end{array}$ & Recommended range & CMA \\
\hline Moisture & $\begin{array}{l}\text { Moisture in the sand dilutes the acid catalyst and slows the condensation curing reaction. } \\
\text { Sand with a moisture level above 0.2\% will significantly affect the cure rate, cured } \\
\text { strength, and sand flowability [13]. }\end{array}$ & $<$ \\
$0.2 \%$ \\
\hline
\end{tabular}




\subsubsection{Chemical composition procedure}

The chemical composition procedure will determine whether the sand is compatible with acid-catalysed binder systems and the metal being casted. The CMA for the process is highlighted in Table 8.

Table 8: Chemical composition procedure CMA

\begin{tabular}{|l|l|l|}
\hline $\begin{array}{l}\text { Critical } \\
\text { attributes }\end{array}$ & Recommended range & CMA \\
\hline ADV & $\begin{array}{l}\text { The chemical composition has a direct effect on the ADV, and is used to determine } \\
\text { whether a sand could be used in acid-catalysed binder systems [18]. As } \\
\text { demonstrated in Table 3, sands with an ADV of 6 ml and lower are deemed } \\
\text { compatible with acid catalysed binder systems [18]. High ADV sands offer low mould } \\
\text { strengths, and require high amounts of acid catalyst, which influences the flow } \\
\text { behaviour of the coated sand owing to the increase in capillary forces. }\end{array}$ & ADV $\leq$ ml \\
\hline $\begin{array}{l}\text { Sintering } \\
\text { temperature }\end{array}$ & $\begin{array}{l}\text { The sintering temperature specifies the melting temperature of the sand; if reached } \\
\text { during casting, it may cause burn-on defects. According to Brown, a high purity } \\
\text { silica sand has a sintering point of } 1450^{\circ} \mathrm{C} \text { and above [18]. However, the sintering } \\
\text { temperature requirement depends on the pouring temperature, which is specified } \\
\text { by the foundry. }\end{array}$ & $\begin{array}{l}\text { Sintering } \\
\text { point } \geq \\
1450^{\circ} \mathrm{C}\end{array}$ \\
\hline
\end{tabular}

\subsubsection{Resting period}

The resting period activity is necessary to improve the flowability of the coated sand. The CPP that was identified for the resting period activity is shown in Table 9.

Table 9: Resting period CPP

\begin{tabular}{|l|l|l|}
\hline Activity & Recommended range & CPP \\
\hline $\begin{array}{l}\text { Resting } \\
\text { period }\end{array}$ & $\begin{array}{l}\text { A study conducted by Dady, Nyembwe \& Van Tonder proved that the flowability of } \\
\text { sulphonic acid-coated sand increases over a period of 48 hours [19]. It is therefore } \\
\text { recommended to allow a minimum resting period of two days, as suggested by the } \\
\text { chemical supplier [17]. }\end{array}$ & $\begin{array}{l}\text { Minimum of } \\
\text { two days }\end{array}$ \\
\hline
\end{tabular}

\subsubsection{Catalyst verification procedure}

The catalyst verification procedure is used to verify that the sand adheres to the acid-coating requirements. The CMA that was identified for this procedure is shown in Table 10.

Table 10: Catalyst verification procedure CMA

\begin{tabular}{|l|l|l|}
\hline $\begin{array}{l}\text { Critical } \\
\text { attributes }\end{array}$ & Recommended range & CMA \\
\hline $\begin{array}{l}\text { \% } \\
\text { acid/sand } \\
\text { weight }\end{array}$ & $\begin{array}{l}\text { Too much acid causes the furan resin to become brittle, resulting in a decrease in } \\
\text { the cohesiveness of the mould or core. Too little acid will result in a prolonged } \\
\text { curing time, which will influence the final strength of the mould or core [20]. The } \\
\text { OEM sand is coated with an acid supplied by ASK chemicals that was specially } \\
\text { developed for AM technologies. ASK's advice was to keep the acid content between } \\
\begin{array}{l}0.2 \% \text { and 0.4\% based on sand weight (BOS). However, according to an ASK research } \\
\text { and development engineer, a 0.3\% BOS coating was found to be the optimal coating } \\
\text { ratio [17]. }\end{array}\end{array}$ & $\begin{array}{l}0.3 \% \text { BOS. } \\
\text { With an } \\
\text { allowable } \\
\pm 0.1 \% .\end{array}$ \\
\end{tabular}

\subsubsection{Flowability procedure}

The flowability procedure is used to verify whether the coated sand is suitable to be used in the Voxeljet VX1000 recoater system. The CMA that was identified for this procedure is highlighted in Table 11.

Table 11: Flowability procedure CMA

\begin{tabular}{|l|l|l|}
\hline $\begin{array}{l}\text { Critical } \\
\text { attributes }\end{array}$ & Recommended range & CMA \\
\hline $\begin{array}{l}\text { Angle of } \\
\text { repose }\end{array}$ & $\begin{array}{l}\text { A study conducted by Dady et al. [19] showed that an increase in the sulphonic acid coating } \\
\text { affected the flowability of the sand. During the study, three silica samples were coated } \\
\text { with } 0.3 \%, 0.6 \% \text {, and 0.9\% BOS sulphonic acid coating respectively. The results showed that } \\
\text { the 0.3\% BOS coating offered a uniform recoating wave, which indicated that the sand } \\
\text { adhered to the recoater specifications. The 0.6\% BOS coating resulted in an uneven } \\
\text { recoating wave with signs of clotting, which increased the possibility of a recoating error. } \\
\text { Although this sand was printable, it was not recommended owing to its unpredictable flow } \\
\text { properties. The 0.9\% BOS coating proved to be incompatible with the printing process owing } \\
\text { to recoater blockages and weak flowability. The flowability ratings of the three sand } \\
\text { coatings were: } 0.3 \% \text { BOS } \rightarrow \text { Good }\left(31^{\circ}-35^{\circ}\right) ; 0.6 \% \text { BOS } \rightarrow \text { Poor }\left(46^{\circ}-55^{\circ}\right) ; 0.9 \% \text { BOS } \rightarrow \text { Very } \\
\text { poor }\left(56^{\circ}-65^{\circ}\right)[19] .\end{array}$ & $\begin{array}{l}\text { Angle } \\
\text { poos }\end{array}$ \\
\hline
\end{tabular}




\subsection{Quality risk assessment}

The quality risk assessment (QRA) identifies the quality risks associated with the sand coating process. Any factor with an uncertain probability of occurring that can influence the outcome of a project is considered to be a risk or a hazard. The risks were identified in the literature review used to identify the CQAs. The Ishikawa diagram, also called a 'cause and effect diagram', was used to demonstrate the risks that could influence the quality of the chemical coating process. The diagram is given in Figure 5.

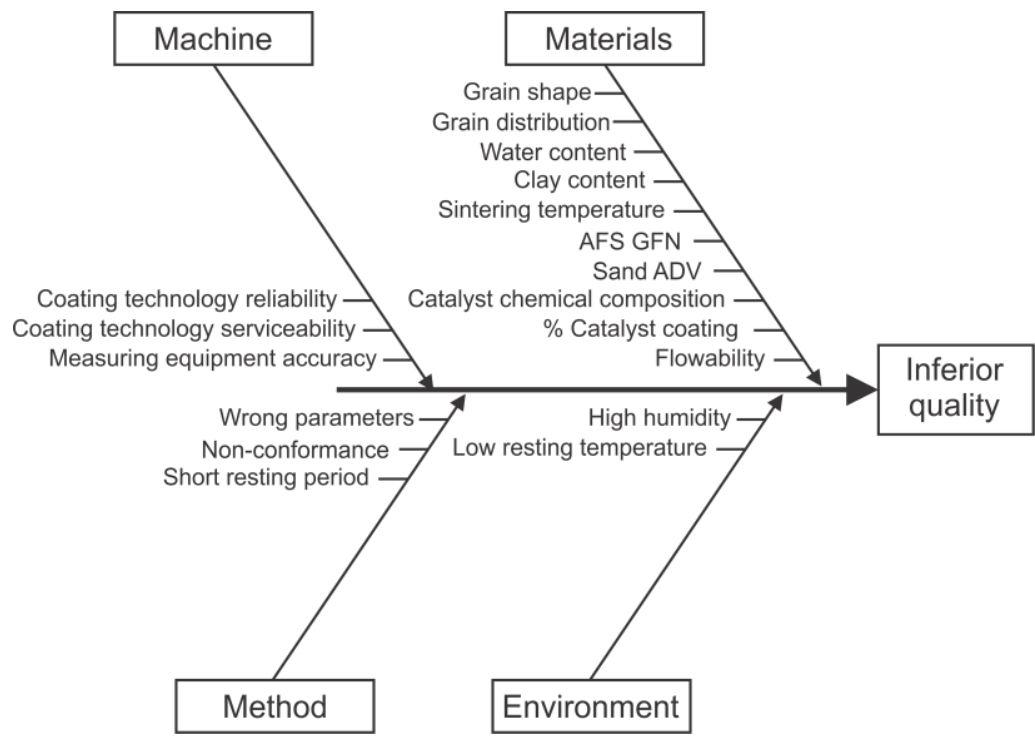

Figure 5: Ishikawa diagram

\subsection{Design space}

The design space (DS) can be defined as a multidimensional combination and interaction of input variables and process parameters that have been shown to assure the quality [6]. Taking this definition into consideration, the DS will specify to what extent the chemical coating process needs to be controlled; this is show in Table 12.

Table 12: Design space

\begin{tabular}{|l|l|l|l|}
\hline Process & Procedures \& activities & CQAs & CPP and CMA \\
\hline Chemical coating & Physical classification & AFS GFN & $50-60$ (if not differently specified) \\
\cline { 3 - 4 } & & Sand distribution & $3-5$ sieve \\
\cline { 3 - 4 } & & Grain shape & Rounded to sub-rounded \\
\cline { 2 - 4 } & AFS clay content & $<0.3 \%$ \\
\cline { 2 - 4 } & Cleanliness & Moisture & $<0.2 \%$ \\
\cline { 2 - 4 } & Chemical composition & ADV & $\leq 6 \mathrm{ml}$ \\
\cline { 2 - 4 } & Sintering temperature & $\geq 1450^{\circ} \mathrm{C}$ \\
\cline { 2 - 4 } & Resting period & Resting period & Min 2 days \\
\hline & Catalyst verification & Coating ratio & $0.3 \% \mathrm{BOS} \pm 0.1 \%$. \\
\cline { 2 - 4 } & Flowability verification & Angle of repose & $\leq 45^{\circ}$ \\
\hline
\end{tabular}

\subsection{Control strategy}

As highlighted in Table 12, several CPPs and CMAs need to be controlled, and require control strategies to ensure the repeatability of the results [6]. The control strategies (CS) that were identified for the chemical coating process are based on standardised testing methods. The CSs for the CQAs are shown in Table 13. 
Table 13: CQAs control strategy

\begin{tabular}{|c|c|c|}
\hline CQAs & $\begin{array}{l}\text { Monitoring methods } \\
\text { (standardised testing } \\
\text { method) }\end{array}$ & Description \\
\hline $\begin{array}{l}\text { AFS GFN \& sand } \\
\text { distribution }\end{array}$ & AFS GFN 1106-12-S & $\begin{array}{l}\text { Determine the particle size distribution and AFS GFN of loose } \\
\text { dry sand using the standard test sieves standard (AFS GFN). }\end{array}$ \\
\hline Grain shape & AFS 1107-00-S & Standard test for determining the grain's shape. \\
\hline ADV & AFS 1114-00-S & Standard test for acid demand value (ADV). \\
\hline AFS clay content & AFS 2110-04-S & Standard test for determining the percentage of clay. \\
\hline Moisture & AFS 2216-00-S & $\begin{array}{l}\text { Standard test for determining the percentage of moisture in a } \\
\text { sand sample. }\end{array}$ \\
\hline $\begin{array}{l}\text { Sintering } \\
\text { temperature }\end{array}$ & VGD-Merkblatt p26 & $\begin{array}{l}\text { Method used to determine the sintering temperature of } \\
\text { refractory material }\end{array}$ \\
\hline Coating ratio & AFS 5100-12-S & $\begin{array}{l}\text { Loss of ignition (LOI). Determining the weight change of a } \\
\text { sample when fired. The weight loss is a result of the } \\
\text { volatilisation of organics substances. }\end{array}$ \\
\hline Angle of repose & ASTM C1444-00 & $\begin{array}{l}\text { Standard test method for measuring the angle of repose of free- } \\
\text { flowing mould powders. }\end{array}$ \\
\hline
\end{tabular}

It is important to note that a sand sampling standard should be used when taking samples for the control strategies listed in Table 13. Two main standards are available for sampling from either a sand pile or bagged sand, as shown in Table 14.

Table 14: Sand sampling control strategies

\begin{tabular}{|l|l|l|}
\hline Procedure & Standard & Description \\
\hline Sand sampling & AFS 1101-13-S & Sampling of a sand pile \\
\cline { 2 - 3 } & AFS 1104-13-S & Sampling of bagged sand \\
\hline
\end{tabular}

\subsection{Continuous improvement strategies}

The continuous improvement strategies (CIS) list the approaches to gradually and continually improving products, services, or processes through constant review, measurement, and action. ISO9001 specifically highlights the importance of integrating the deming cycle into all business processes and procedures. The deming cycle consist of a 'plan do check act cycle' (PDCA) to ensure continuous improvement. For this reason, the Demming cycle was selected as a suitable continuous improvement strategy [6].

\section{SUMMARY OF RESULTS}

Through applying the QbD methodology, it was established that the desired quality characteristics of the chemical-coated sand included:

- $\quad$ Reliability - The coated sand consistently performs within the specification of the AM technology.

- Conformance - Adheres to the requirements of the target group, which was identified as sand foundries.

By focusing on these characteristics, numerous critical quality attributes were identified. They should be controlled within an appropriate limit, range, or distribution to ensure that the quality characteristics are met. The CQAs included the AFS GFN, grain shape, AFS clay content, sand moisture, sintering temperature, acid demand value, coating ratio, and sand flowability. The CQAs were used to develop a chemical coating process that identified the necessary procedures and activities to ensure the quality of the coated sand. The process, procedures, and activities that were identified are shown in Figure 6, which also incorporates the PDCA cycle as a continuous improvement strategy. The critical material attributes and process parameters for each of the procedures and activities were also identified, and served as the quality requirements for the coated sand. 


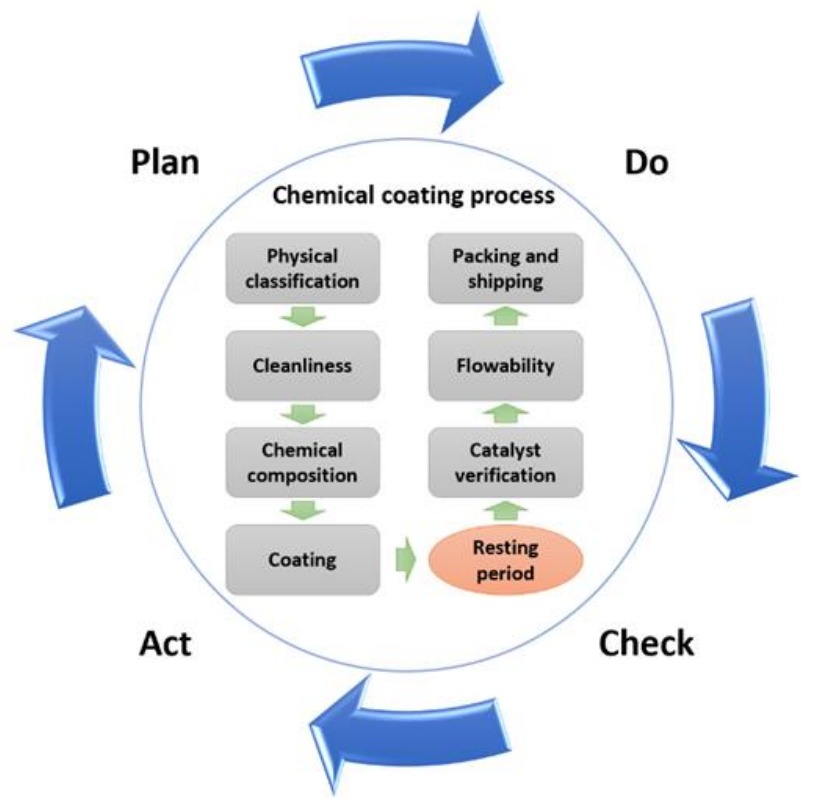

Figure 6: Chemical coating process

Using the results in section 4, a quality assurance framework was developed, as shown in Table 15.

\section{Table 15: QA framework}

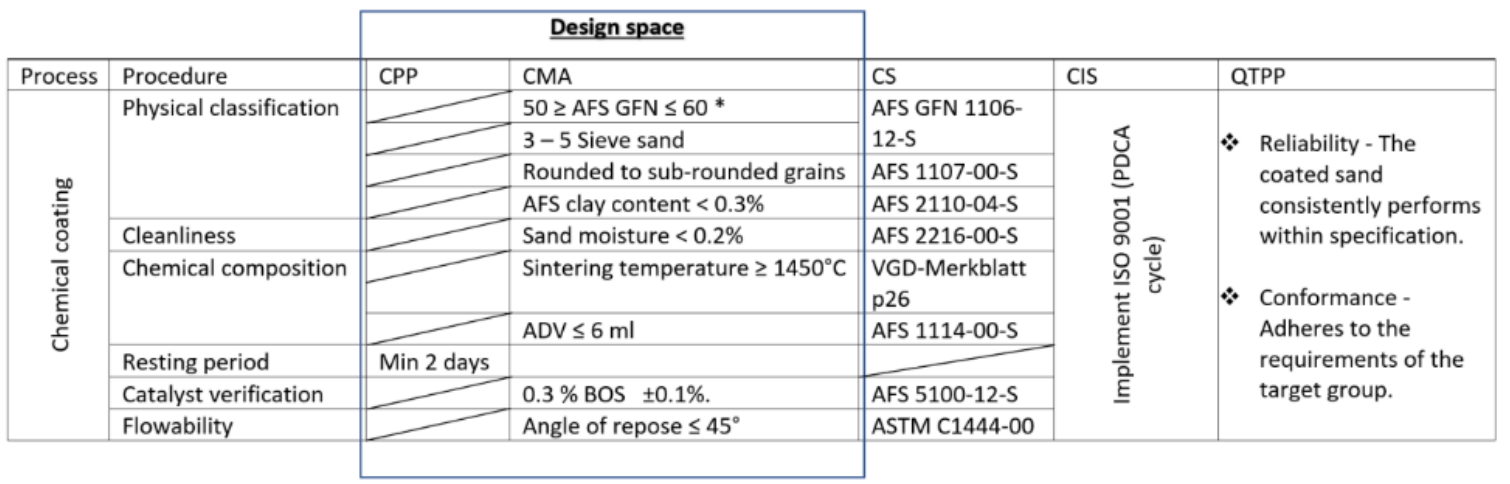

\section{CONCLUSION}

The purpose of the research project presented in this paper was to develop a quality assurance framework for the local production of chemical-coated sand used in the Voxeljet VX1000 printing process. The QbD methodology was used to develop the framework, as shown in Table 15. The framework can be used to develop the necessary processes, procedures, and activities to ensure that the end product (printed moulds and cores) adheres to the clients' quality requirements.

\section{REFERENCES}

[1] Hawaldar, N. \& Zhang, J. 2018. A comparative study of fabrication of sand casting mold using additive manufacturing and conventional process. The International Journal of Advanced Manufacturing Technology, 97, pp. 1037-1045.

[2] Van Tonder, P.J.M. 2019. Development of a quality assurance framework for chemical coated sand used in additive manufacturing technologies. M.Eng. thesis, North West University.

[3] CSIRO Research. n.d. Voxeljet sand printer. Available at: https://research.csiro.au/metals/addmanufacturing/aus-innovation/voxeljet-sand-3d-printer/ Date of access: 5 April 2018.

[4] Pešić, M.A., Milić, V.J. \& Stanković, J. 2012. Significance of business quality management for increasing competitiveness of Serbian economy. Serbian Journal of Management, 7(1), pp. 147-170. 
[5] ISO 9000 Store. n.d. Processes, procedures and work instructions. Available at: https://the9000store.com/iso9001-2015-requirements/iso-9001-2015-context-of-the-organization/processes-procedures-work-instructions/. Date of access: 13 December 2018.

[6] Naidu, N.V.R., Badu, K.M. \& Rajendra, G. 2013. Total quality management. New Delhi: New Age International Publishers.

[7] Garvin, D.A. 1987. Competing on the eight dimensions of quality. Harvard Business Review, 87, pp 101-109.

[8] Martinez-Marquez, D., Mirnajafizadeh, A., Carty, C.P. \& Stewart, R.A. 2018. Application of quality by design for 3D printed bone prostheses and scaffold. PLOS ONE, 13(4), e0195291.

[9] Schleg, F.P. 2003. Technology of metal casting. Illinois: American Foundry Society.

[10] Woods, K. 2018. Sand distribution effects on three dimensional printed sand properties. M.Sc. thesis, University of Northern lowa.

[11] Jain, P.L. 2008. Principles of foundry technology. New Delhi: Tata McGraw-Hill Publishing Company Limited.

[12] Holtzer, M., Górny, M. \& Danko, R. 2015. Microstructure and properties of ductile iron and compacted graphite iron castings. Heidelberg: Springer.

[13] Mancuso Chemicals Ltd. 2005. Process overview: Chemistry and use of furan binders. Available from: http://www.mancusochemicals.com/wp-content/uploads/2013/05/Furan-Binder-Use.pdf. Date of access: 1 December 2018.

[14] Chakrabarti, B.K. \& Acharyya, M. 1992. Instabilities in a sandpile under vibration. Journal of Physics, 2, pp. 289392.

[15] Harireche, O., Alani, M. \& Faramarzi, A. 2013. A toroidal approximation of capillary forces in polydisperse granular assemblies. Granular Matter, 15(5), pp. 573-581.

[16] Haque, M. n.d. Variation of flow property of different set of formulas of excipients against variable ratio of different diluents. B.Pharm. thesis. East West University.

[17] Polsakiewicz, D. 2018. Harter40-100. E-mail from Polsakiewicz, D.

[18] Brown, J.R. 2010. Foseco foundryman's handbook. Oxford: Butterworth-Heinemann.

[19] Dady, O., Nyembwe, K. \& Van Tonder, P.J.M. 2018. Sulfonic acid coating of refractory sand for three-dimensional printing applications. Rapid Product Development Association of South Africa (RAPDASA) 2018 Conference Proceedings. Place: Braamfontein, Johannesburg.

[20] Frohn, M., Kock, D. \& Antoni, G. 2014. Catalysts comprising methane sulfonic acid for the acid hardening method. Patent: US 8919421B2. Available at: https://patents.google.com/patent/US8919421B2/en. Date accessed: 15 March 2019. 